\title{
The FeedSmart "Cost of Supplements and Cost of Pasture" models
}

\author{
D.C. SMEATON ${ }^{1}$, S.T. RAINS ${ }^{2}$ and G.R.J. PEYROUX ${ }^{3}$ \\ ${ }^{1}$ AgResearch Limited, Ruakura Research Centre, PB 3123, Hamilton \\ ${ }^{2}$ AgResearch Limited, Lincoln Research Centre, PB 4749, Lincoln \\ ${ }^{3} \mathrm{AgResearch} \mathrm{Limited,} \mathrm{Invermay} \mathrm{Research} \mathrm{Centre,} \mathrm{PB} \mathrm{50034,} \mathrm{Invermay}$
}

duncan.smeaton@agresearch.co.nz

\begin{abstract}
The "FeedSmart" extension programme, focused on improved feed planning for sheep and beef farmers includes two computer models to assist with decision making. The Cost of Pasture model requires the user to input a farm income and cost structure, and a pasture growth curve. It calculates the costs of growing pasture on a dry matter (DM) basis. Cost of capital is included in the calculations and return on capital is also calculated. The Cost of Supplements model provides a simple sequence of steps to calculate the returns from feeding supplements at a given purchase price. All costs and wastage items are incorporated and technical tool tips are provided to assist the model user. Model results showed that in terms of growing pasture on New Zealand sheep and beef farms the cost of pasture was, on average, 3.3 cents/kg DM in 2006/07, excluding the cost of capital. When costs of capital, excluding stock, were included at an $8 \%$ interest rate, the cost was $12 \mathrm{c} / \mathrm{kg} \mathrm{DM}$. For supplementation, breakeven profitability in a cattle example was achieved at a schedule price of $400 \mathrm{c} / \mathrm{kg}$ carcass weight, if the supplement could be fed for $27 \mathrm{c} /$ $\mathrm{kg}$ DM. Nitrogen fertiliser falls under this limit.
\end{abstract}

Keywords: cost of pasture, cost of supplements, cost, pasture, supplements

\section{Introduction}

Farmers are in the business of converting energy from the sun into a chemical form which can be sold. They remain in business long term if they can do this at a profit. Costs include the costs of providing feed to animals and the costs of animal management and production. The primary feed source on New Zealand sheep and beef farms is pasture. Very few farmers know the cost or value of growing pasture per kg dry matter (DM) or per MJ of metabolisable energy. Instead, they tend to work at a whole farm level, comparing total costs, such as fertilisers, vehicles, repairs and maintenance against gross income, to determine levels of profitability. Even so, the factors driving farm profit are the unit costs of pasture versus the returns that can be generated from that pasture.

Farmers cannot access pasture on which to grow animals unless they either purchase a farm or rent or lease grazing land. Therefore, in cost of pasture calculations, allowance for the cost of capital (land and improvements) should occur.

Supply of pasture is seasonal and subject to climatic variation. Farmers can manage this by varying animal feed intake and hence seasonal performance. Alternatively, they may vary the number of animals on the farm or introduce supplementary feed from off the farm. Knowledge of the profitability of the latter option should be an essential part of decisions about whether to purchase supplements or not.

This paper describes two models that enable sheep and beef farmers to calculate the costs and profitability of both pastures and supplements. Typical results are presented.

\section{Methods}

Two stand-alone models were built using Visual Basic .NET 2.0 Windows Forms / Microsoft Visual Studio 2008 / XML data templates. The models are simple, carry out the calculations in a step-wise fashion and are designed to be used logically, without reference to instruction manuals. They both require data input from the user. "Tool tips" are provided to assist in terms of how to make appropriate data entry assumptions, such as wastage during storage, utilisation at feeding out, and costs of feeding out.

\section{Cost of pasture}

The calculation template for the cost of pasture model was based on the farm budget models routinely produced by MAF for their Farm Monitoring Reports (2006) and Meat \& Wool New Zealand's Economic Service (2008). It also closely follows headings and cost categories used on most farm accounts.

The model was set up listing all income and cost categories with data entry cells to be filled in for each category. In addition, each data value was multiplied by a percentage value to apportion costs to either pasture or animal production (Fig. 1). The percent allocation can be altered by the user and the percent values shown in Figure 1 are the default values chosen by the authors. There is no published information to help in this regard. Costs associated with animal production are also displayed on a separate screen tab and are the total cost less the allocated costs for pasture production. As with the published budgets noted above, there is an adjustment section in 
Figure 1 Screen shot of expenses panel for the cost of pasture model showing cost category, total amount and proportion of that amount (\%) applied to pasture growth. Not all cost items are shown in this figure.

\begin{tabular}{l|r|r|}
\hline EXPENDITURE attributable to DM production & Whole farm total \$ & $\%$ for DM production \\
\hline Workinq expenses & 25,000 & \\
\hline Permanent wages (incl. manager) & 0 & $40 \%$ \\
\hline Casual wages & 3,500 & $20 \%$ \\
\hline Electricity & 21,000 & $10 \%$ \\
\hline Animal Health & 0 & $0 \%$ \\
\hline Breeding & 7,000 & $0 \%$ \\
\hline Freight (not elsewhere deducted) & 18,000 & $20 \%$ \\
\hline Shearing expenses & 0 & $0 \%$ \\
\hline Dairy expenses & 14,000 & $0 \%$ \\
\hline Feed/Grazing & 5,000 & $0 \%$ \\
\hline Agricultural contracting & 0 & $50 \%$ \\
\hline Irrigation electricity & 4,000 & $100 \%$ \\
\hline Crop sowing & 8,000 & $100 \%$ \\
\hline Regrassing costs & 10,000 & $100 \%$ \\
\hline Nitrogen & 40,000 & $100 \%$ \\
\hline Fertiliser & 5,000 & $100 \%$ \\
\hline Lime & 7,500 & $100 \%$ \\
\hline Weed \& Pest & 6,000 & $100 \%$ \\
\hline Rent and or leases & 5,000 & $50 \%$ \\
\hline Other & 179,000 & $50 \%$ \\
\hline Total & & 94,250 \\
\hline & &
\end{tabular}

Figure 2 Screen shot of cost of pasture Summary panel. Results are expressed on a whole farm, per hectare and per kg DM basis.

\begin{tabular}{|l|r|r|r|}
\hline Summary & Total & \$/ha & c/kg DM \\
\hline Gross Farm Revenue & 395,000 & 658 & 6.93 \\
\hline Operating Costs (excl. interest) & 355,000 & 592 & 6.23 \\
\hline Operating Profit (excl. interest = EBIT) & 40,000 & 67 & 0.7 \\
\hline Profit (incl. interest costs) & $-536,000$ & -893 & -9.4 \\
\hline Return on Capital & $0.56 \%$ & & \\
\hline Cost of growing pasture (excl. interest) & 171,400 & 286 & 3.01 \\
\hline Cost of growing pasture (incl. interest) & 747,400 & 1,246 & 13.11 \\
\hline
\end{tabular}

the model to account for the wages of management and depreciation.

The model includes a section to allow the user to insert pasture production ( $\mathrm{kg} \mathrm{DM} / \mathrm{ha} /$ year and per day), farm area, farm income and borrowings with interest rates, including the farmer's own expected return on invested capital. After the appropriate arithmetic calculations, the results are displayed at the bottom on the data entry section and also at the top of the screen in a summary panel (Fig. 2).

\section{Cost and returns from feeding supplements}

This model was developed to calculate the marginal response to a supplement using the feed intake response functions described by Nicol \& Brookes (2007) and Geenty \& Rattray (1987). Inputs include costs of supplement, wastage, utilisation, ME content, unsupplemented pasture intake and liveweight gain and the schedule value of that gain. The results are presented in a summary panel at the top of the model as shown in Figure 3. The supplementation model is for use with 
growing or finishing sheep and cattle only. Accomodating pregnancy and lactation requirements in the model were issues of complexity beyond the scope of this project. Other more complex models such as "Farmax" are available for this purpose.

Substitution rate must also be entered into the model. Choosing an appropriate figure for pasture substitution in feed supplementation models such as this is problematic due to the wide range of factors affecting substitution (Clark \& Woodward 2007). The decision was made to leave the entry of this important figure up to the user due to difficulties of trying to programme response functions for substitution into the model itself. The risks of the model delivering incorrect information, unbeknown to the user, were deemed to be too high. Instead, an extensive tool tip on substitution was provided for the user to make his or her own decision on an appropriate value. A range of substitution levels can easily be entered to test the impacts of substitution on supplement profitability.

\section{Error commentary}

The models do not provide error or variance information. They are simply a tool to ensure the user includes all aspects of calculating the answers they require in a convenient form. Sensitivity to assumptions can be easily tested by changing input values. Clearly, if the user enters inappropriate information, the models will provide inappropriate answers. Interpretation and evaluation of output by the user is also required. The only built-in check is a "maximum theoretical intake exceeded" warning flag in the Supplement Cost-Benefit model.

Validation of the feed response functions in the supplements model was made against Boom \& Sheath (1998) and from review information provided in Smeaton (2003) and Clark \& Woodward (2007).

\section{Simulation work}

The models were used to provide the results reported in this paper. The Cost of Pasture model was run using information derived from the standard models supplied by Meat $\&$ Wool New Zealand as a result of their farm survey work. Pasture growth rates for the models followed typical growth profiles for the regions modelled, scaled to a total annual pasture growth rate per hectare. Annual growth was estimated based on total SU wintered per hectare as described for each farm modelled by the Economic Service, multiplied by $740 \mathrm{~kg} \mathrm{DM} / \mathrm{SU}$ (Webby et al. 1995). The capital values used for each model farm (excluding stock) were estimated as $\$ 800$ / total SU wintered. For a whole-farm return on capital figure, $\$ 100 / \mathrm{SU}$ was added for the capital cost of stock.

The Supplements Cost-Benefit model was used to determine the profitability of supplementation and to derive various break-even scenarios for the use of supplements and to demonstrate the impacts of substitution and feed utilisation (the percentage of supplement offered which is actually eaten). Results are presented for cattle only, in the interests of brevity. Supplementation of lambs in particular can also be problematic due to rejection issues which can lead to very poor utilisation. With these animals, provision of specialist forages is likely to be more successful (Clark \& Woodward 2007). Even so, the model could be used to provide information on the cost-benefits of providing this feed for these animals.

\section{Results and Discussion Cost of pasture}

Figure 4 shows costs of pasture production for five regions of New Zealand as derived from the model for the 2006-07 season. Costs of pasture production excluding interest on total capital were quite consistent at an average of $3.3 \mathrm{c} / \mathrm{kg}$ DM. Not shown in the figure are the animal production costs at an average of $4.3 \mathrm{c} / \mathrm{kg}$ DM. This latter figure is biased upwards a little by the fact that the Marlborough-Canterbury farms have a significant area of cash cropping on their properties amounting to $25 \%$ of gross farm income.

Of particular interest was the impact of the cost of

Figure 3 Screen shot of supplement cost-benefit model showing the Results Summary panel. Results are expressed on a whole farm and c/kg DM basis.

\begin{tabular}{|l|r|r|l}
\hline Summary & c/kg DM & as \% of costs & \\
\hline Profit from feeding supplement & 9.1 & $32 \%$ & Excl Tax \\
\hline & 9.1 & $32 \%$ & Incl Tax \\
\hline & & & \\
\hline Whole farm per year & & Units & \\
\hline Cost & 4,091 & $\$$ & \\
\hline Profit including tax & 1,456 & $\$$ & \\
\hline Extra production & 4,010 & $\mathrm{~kg}$ LWt. & \\
\hline Supplement used & 55 & $\mathrm{t}$ (wet weight) & \\
\hline
\end{tabular}


Figure 4 Costs of growing pasture on sheep and beef farms (c/kg DM) for five farming regions of New Zealand. Results are inclusive and exclusive of the interest cost (at $8 \%$ ) of owning the farms (excluding capital in stock) and are derived from Class 9 All Classes regional average data (2006-07) provided by Economic Service, Meat \& Wool New Zealand.

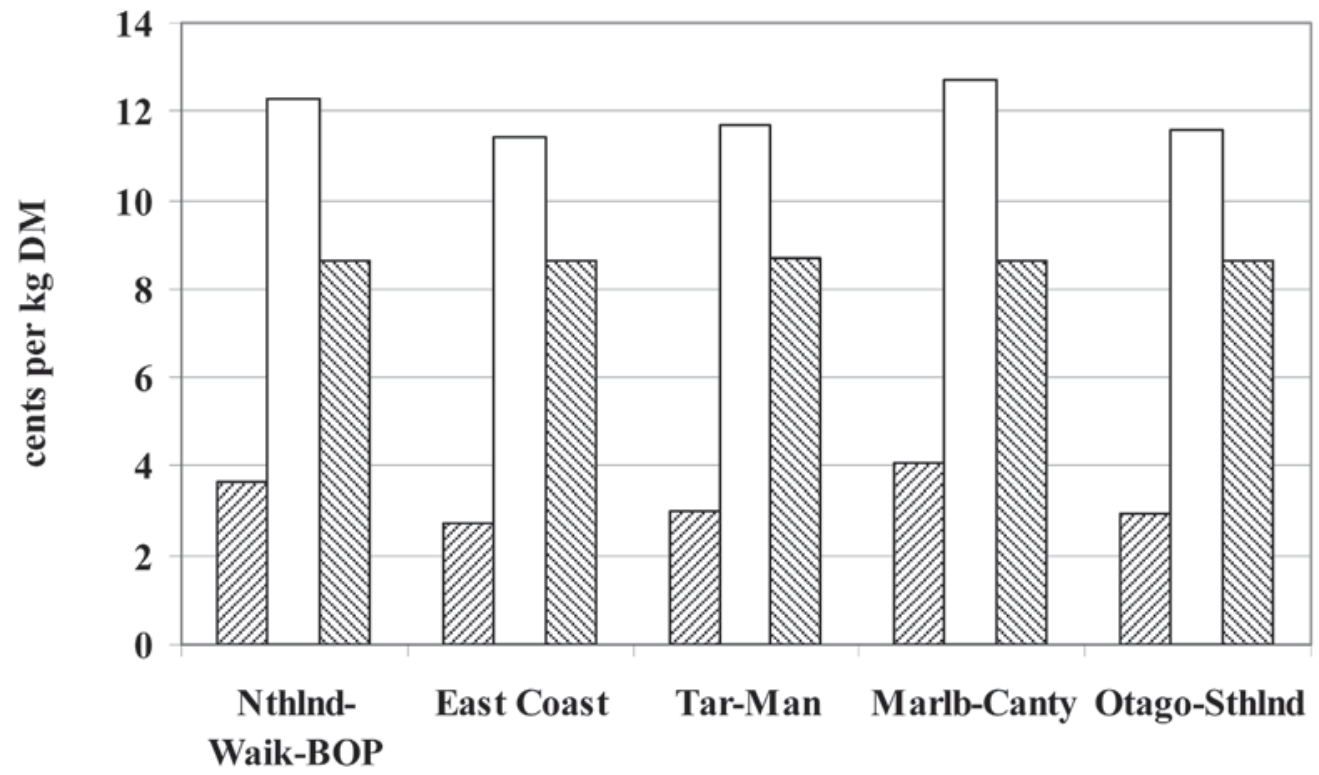

\section{口 Cost of DM excl capital $\square$ Cost of DM incl capital $\varangle$ Cost of DM, capital only}

capital on the costs of growing pasture. This effect (average $8.6 \mathrm{c} / \mathrm{kg} \mathrm{DM}$ ) was consistent across all farm types as would be expected given that the same valuation figure excluding stock of $\$ 800 / \mathrm{SU}$ was used. This surely must be a concern as it affects New Zealand's ability to grow pasture at a low cost.

Return on total capital (land plus stock, Table 1) likewise was quite consistent at an average of $1.0 \%$. This figure compares with $-0.1 \%$ as published by Meat \& Wool New Zealand Economic Service (2008). Discrepancies between the two calculation sources are presumably due to differences in estimates of total capital. Reference to recent sales reported in the farming press and discussions with Economic Service staff indicate that farm values can vary widely depending on locality, potential for land use change etc. The implication from our $1 \%$ profit figure, is that farmers purchasing sheep and beef properties would require $89 \%$ equity to achieve a breakeven profit result, after paying interest on debt, if the cost of borrowed money was 9\%. Although this appears to be poor return on investment, capital gain at an average of $9 \%$ in the last 15 years for New Zealand sheep and beef farmland makes the investment attractive but with poor cash returns.

Estimates of likely returns to sheep and beef farms for
2008-09 (Meat \& Wool New Zealand Economic Service 2008) show that on average since 2006-07, gross farm income will have increased by $14 \%$ and total farm working expenses will have increased by $8 \%$.

\section{Cost and returns from feeding supplements: Validation}

The model appeared to be simulating the marginal response to supplement correctly. Smeaton (2003) and Clark \& Woodward (2007) observed that response rates to supplements are very variable. Results with growing beef cattle on pasture indicate that it frequently takes 4$10 \mathrm{~kg}$ of supplementary DM to produce an extra $1 \mathrm{~kg}$ of liveweight gain. Boom \& Sheath (1998) achieved responses of 5 to $7 \mathrm{~kg} \mathrm{DM} / \mathrm{kg}$ LWG in finishing cattle fed hill country pasture and maize grain. The results below show the model was forecasting responses to supplements in this range.

Profitability of feeding supplements: Modelled results The modelled results (shown in the first row of Table 2) and also Figure 5 concur with the generally held view that feeding supplements to sheep and cattle in New Zealand is generally unprofitable. Table 2 also shows that the requirements for breakeven returns from 
Table 1 Return (EBIT) on total capital (\%) for five farming regions of New Zealand. Results are derived from Class 9 All Classes regional average data (2006-07) provided by Economic Service, Meat \& Wool New Zealand. Total capital, including stock estimated as $\$ 900 / \mathrm{SU}$ times total SU wintered. Farms in Marlborough-Canterbury are undervalued by this method which ignores areas not grazed due to cropping programmes.

\begin{tabular}{lccccc}
\hline & $\begin{array}{c}\text { Northland- } \\
\text { Waikato-BOP }\end{array}$ & $\begin{array}{c}\text { East } \\
\text { Coast }\end{array}$ & $\begin{array}{c}\text { Taranaki- } \\
\text { Manawatu }\end{array}$ & $\begin{array}{c}\text { Marlborough- } \\
\text { Canterbury }\end{array}$ & $\begin{array}{c}\text { Otago-Southland } \\
\text { Southland }\end{array}$ \\
\hline Return on capital (\%) & 0.8 & 1.0 & 0.9 & 1.3 & 1.2 \\
\hline
\end{tabular}

Table 2 A modelled likely result from feeding supplement to cattle and four scenarios showing requirements to breakeven assuming: $350 \mathrm{~kg}$ start weight, zero supplement-free liveweight gain, pasture and supplement ME both $10.5 \mathrm{MJ}$ ME/kg DM, wastage during storage $5 \%$, utilisation of offered supplement $90 \%$, variable costs of feeding out $0.0 \mathrm{c} / \mathrm{kg} \mathrm{DM}$.

\begin{tabular}{lccccc}
\hline Comment & $\begin{array}{c}\text { Supplement } \\
\text { price }(\$ / \mathrm{t} \mathrm{DM})\end{array}$ & $\begin{array}{c}\text { Substitution } \\
\text { rate }(\%)\end{array}$ & $\begin{array}{c}\text { Schedule } \\
(\mathrm{c} / \mathrm{kg} \mathrm{CW})\end{array}$ & $\begin{array}{c}\text { Marginal response } \\
(\mathrm{kg} \mathrm{DM} / \mathrm{kg} \mathrm{LWG})\end{array}$ & $\begin{array}{c}\text { Profit result } \\
(\mathrm{c} / \mathrm{kg} \mathrm{DM})\end{array}$ \\
\hline Likely result* & 360 & 30 & 400 & 6.3 & -10.9 \\
\multirow{3}{*}{ Breakeven scenarios } & 200 & 30 & 300 & 6.3 & 0 \\
& 305 & 20 & 400 & 5.5 & 0 \\
& 266 & 30 & 400 & 6.3 & 0 \\
& 301 & 30 & 450 & 6.3 & 0 \\
\hline
\end{tabular}

*At medium term schedule prices ruling September 2008.

supplementation for four different scenarios exclude all commonly available supplements except nitrogen. Breakeven is the point where marginal return equals marginal cost, so that at higher costs, no further investment in supplement should occur.

The cost of nitrogen $(\mathrm{N})$ as a supplement was estimated at $16 \mathrm{c} / \mathrm{kg}$ DM assuming a cost for urea at $\$ 1120 / \mathrm{t}$ landed on the ground and a 15:1 response to added $\mathrm{N}$ (Lambert et al. 2007). This makes it comfortably profitable provided the extra pasture is utilised although it excludes any potential pasture composition and environmental costs that might subsequently accrue to regular $\mathrm{N}$ fertiliser use (Warren King, pers.comm.). At the present time (September 2008) no other purchased supplementary feed is available for less than $\$ 360 / \mathrm{t} \mathrm{DM}$ in New Zealand although this may be higher than the longer run average value due to the recent drought in New Zealand.

If present levels of optimism for beef and lamb prices are maintained or exceeded (bottom two rows in Table 2 ), breakeven prices for purchasing supplements would occur at $\$ 266$ to $\$ 305 / \mathrm{t} \mathrm{DM}$ assuming low substitution rates, low storage losses, high utilisation rates at feeding out and low to nil feeding out costs. In fact, feeding out costs could be estimated to be $17 \mathrm{c} / \mathrm{kg}$ DM assuming machinery costs of $\$ 100 /$ hour, 2 hours required to feed out per day and 400 animals being fed $3 \mathrm{~kg}$ supplement DM. Arguably, this cost should be added to the results in Table 2 and Figure 5. However, many farmers would not value their machinery costs at the above price on the grounds that they already have the machinery and staff for other purposes so that it is already paid for. Care should be taken that this approach does not become an excuse for a poor financial decision.

Figure 5 shows the impacts of substitution on conversion efficiency of fed supplement and profitability with all other assumptions in the model set at typical, achievable values. The cost of supplement was set at $\$ 350 / \mathrm{t} \mathrm{DM}$ and the schedule was set at $400 \mathrm{c} / \mathrm{kg}$ carcass weight. Even so, all scenarios shown in Figure 5 showed a loss from using supplementary feeds although the loss was negligible when the substitution rate was only $10 \%$. A feature of Figure 5 is the impact of substitution on marginal feed conversion efficiency $(\mathrm{kg} \mathrm{DM} / \mathrm{kg}$ liveweight gain) and the substantial effect of this on profit. Substitution is a significant feature of supplementation although it may have a beneficial pasture sparing effect provided the uneaten (substituted) pasture retains quality and can be eaten by following stock. As described by Smeaton (2003), substitution is often in the range of 0.5 $-0.7 \mathrm{~kg}$ reduction in pasture DM intake $/ \mathrm{kg}$ of extra supplement DM (50 to $70 \%$ ). The poorer the quality of the base pasture rations, the higher the likely rate of substitution will be when animals are being fed above maintenance. Substitution rates of 1:1 can occur.

\section{Conclusions}

We have built two models that enable farmers to calculate the cost of growing pasture and to estimate the profitability of feeding supplements.

In New Zealand at present (2006-07 figures), it costs an average of $3.3 \mathrm{c} / \mathrm{kg}$ DM, excluding the cost of capital, to grow pasture on sheep and beef farms, based on farm 
Figure 5 Effects of substitution rate (\%) on profit from feeding supplement (c/kg DM) and marginal efficiency of use of supplement ( $\mathrm{kg} \mathrm{DM} / \mathrm{kg}$ liveweight gain) fed to cattle. The schedule used was $\$ 4.00 / \mathrm{kg}$ carcass weight; see text for other assumptions.

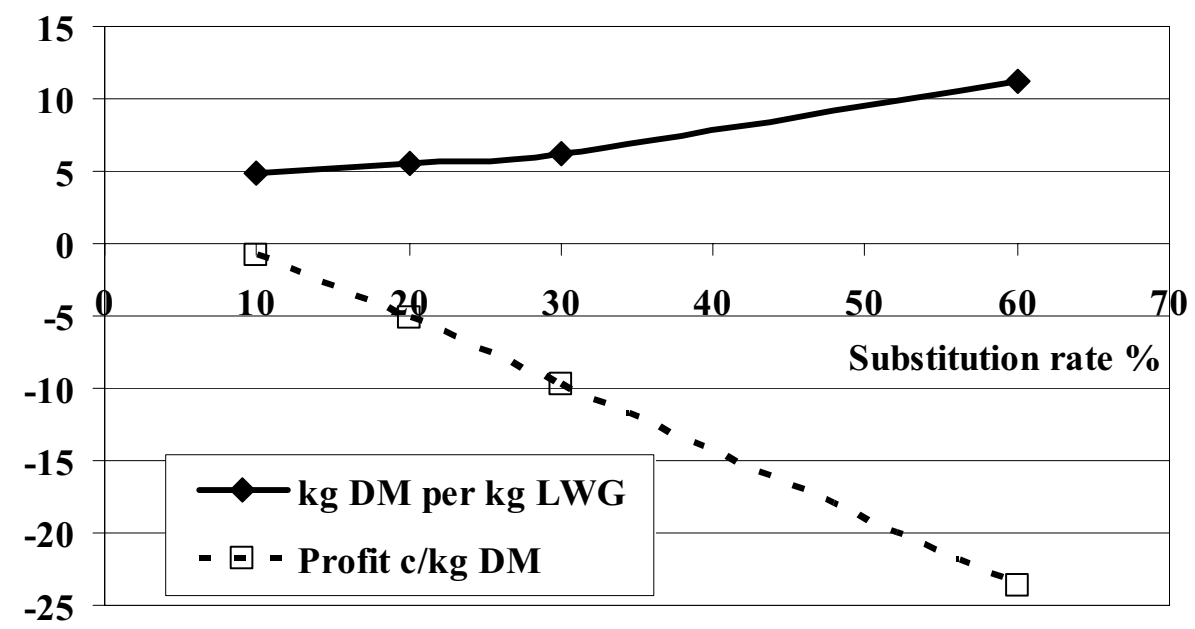

survey data provided by Meat \& Wool New Zealand. Including the cost of owning the farm increases the cost to $12 \mathrm{c} / \mathrm{kg} \mathrm{DM}$. We conclude that this has a potential negative impact on New Zealand's position as a low cost red meat producer.

Supplementation of cattle (and probably sheep) is mostly unprofitable at present feed costs and animal returns except for the use of nitrogen (at June 2008 prices). Supplement utilisation and substitution can have a big impact on profitability. Based on achievable assumptions, the breakeven price for purchasing supplements is about $27 \mathrm{c} / \mathrm{kg} \mathrm{DM}$ at current returns. The costs associated with feeding out supplements, frequently discounted to zero, can be as high as $17 \mathrm{c} / \mathrm{kg} \mathrm{DM}$.

\section{ACKNOWLEDGEMENTS}

The authors wish to thank colleagues for peer review of their models and of this paper and are also grateful to the industry mentor group who critiqued the development of the models. The project was funded by Meat \& Wool New Zealand and the tools can be obtained by contacting them (www.meatandwoolnz.co.nz).

\section{REFERENCES}

Boom, C.J., Sheath, G.W. 1998. Grain supplementation of finishing beef cattle. Proceedings of the New Zealand Society of Animal Production 58: 239-242.

Clark, D.A.; Woodward, S.L. 2007. Supplementation of dairy cows, beef cattle and sheep grazing pasture. pp. $117-131$. In: Pasture and Supplements for Grazing Animals. Occasional Publication No.14 New Zealand
Society of Animal Production. Eds Rattray, P.V.; Brookes, I.M.; Nicol, A.M.

Geenty, K.G.; Rattray, P.V. 1987. The energy requirements of grazing sheep and cattle. pp. 39-53. In: Livestock Feeding on Pasture. New Zealand Society of Animal Production, Occasional Publication No. 10.

Lambert, G.L.; Litherland, A.L.; Webby, R.W. 2007. The role of fertiliser nitrogen in high performing sheep systems. pp. 45-54. In: Proceedings from the 37th Seminar of the Society of Sheep and Beef Cattle Veterinarians, NZVA.

MAF Farm Monitoring. 2006. Sheep and beef monitor farm model budgets for 12 farm types throughout New Zealand. Forecast budgets 2006-07. http:// www.maf.govt.nz/mafnet/rural-nz/statistics-andforecasts/farm-monitoring/2006/sheep-and-beef/ index.htm.

Meat \& Wool New Zealand's Economic Service. 2008 Economics and Statistics, Sheep and Beef Farm survey all classes; Per hectare data for 5 regions. Provisional data 2006-07, estimates 2007-08. www.meatandwoolnz.co.nz.

Nicol, A.M.; Brookes, I.M. 2007. The metabolisable energy requirements of grazing livestock. pp. 151172. In: Pasture and Supplements for Grazing Animals. Occasional Publication No. 14 New Zealand Society of Animal Production. Eds Rattray, P.V.; Brookes, I.M.; Nicol, A.M.

Smeaton, D.C. 2003. Optimising beef production from pasture. pp 61-80., Ch 6. In; Profitable Beef Production. Ed. Smeaton, D.C.. Published by Meat 
\& Wool New Zealand Beef Council, PO Box 121, Wellington.

Webby, R.W.; McCall, D.G.; Blanchard, V.J. 1995. An evaluation of the Stockpol ${ }^{\mathrm{TM}}$ model. Proceedings of the New Zealand Society of Animal Production 55: 145-149. 